\title{
HUBUNGAN PENGETAHUAN DOKTER GIGI DENGAN TINDAKAN PEMBUANGAN SAMPAH MEDIS DI TEMPAT PRAKTEK DOKTER GIGI KOTA PADANG
}

\author{
Vanesa Nadya Olastri", Dhona Afriza ${ }^{* *}$, Widyawati*** \\ *Mahasiswa FKG Universitas Baiturrahmah, Padang \\ ${ }^{* *}$ Bagian Penyakit Mulut, FKG, Universitas Baiturrahmah, Padang \\ ${ }^{* * *}$ Bagian Konservasi Gigi, FKG, Universitas Baiturrahmah, Padang
}

\begin{tabular}{lr}
\hline KATA KUNCI \\
\hline \multicolumn{2}{l}{ Pengetahuan dokter gigi, } \\
pembuangan & sampah \\
medis, tempat & praktek \\
dokter gigi. &
\end{tabular}

PENDAHULUAN

Pembangunan kesehatan bertujuan untuk tercapainya kesadaran, kemauan dan kemampuan untuk hidup sehat bagi setiap penduduk agar dapat mewujudkan derajat kesehatan masyarakat yang optimal. (UU RI. No.36/2009). Menurut Hl.Blum, derajat kesehatan dipengaruhi oleh empat faktor yaitu faktor lingkungan, perilaku, pelayanan kesehatan dan faktor keturunan ${ }^{1}$.

\begin{abstract}
ABSTRAK
Limbah medis salah satunya dihasilkan melalui praktik dokter gigi. Kebanyakan kita tidak menyadari bahwa tempat praktik dokter gigi dapat berpotensi sebagai asal limbah yang membahayakan lingkungan. Apabila sampah medis tersebut tidak dibuang pada tempat yang tepat maka akan menjadi sumber penyebaran penyakit bagi masyarakat sekitarnya. Tujuan Penelitian ini untuk memperoleh hubungan pengetahuan Dokter Gigi dengan tindakan pembuangan sampah medis di tempat praktik Dokter Gigi kota Padang. Desain penelitian ini adalah cross sectional. Jumlah sampel dalam penelitian ini adalah 45 orang. Tehnik pengambilan sampel adalah dengan simple random sampling dengan tehnik lotre. Analisis data univariat dan bivariat. Analisis univariat untuk menggambarkan frekuensi dan persentase, analisis bivariat digunakan uji Fisher's Exact Test. Hasil penelitian menunjukkan bahwa dokter gigi memiliki tingkat pengetahuan yang tinggi mengenai pembuangan sampah medis di tempat praktek dokter gigi $(75,6 \%)$ dibandingkan dengan dokter gigi yang memiliki tingkat pengetahuan yang rendah yaitu (24.4\%). Tindakan dokter gigi tergolong baik dalam pembuangan sampah $(66,7 \%)$ dibandingkan dengan yang buruk $(33,3 \%)$. Hasil uji statistik $p(0,00)<\alpha(0,1)$ sehingga terdapat hubungan antara pengetahuan dokter gigi dengan tindakan pembuangan sampah di tempat praktek dokter gigi kota Padang. Odds Ratio $(90 \% \mathrm{CL}=3,6-123,0)$ dapat disimpulkan bahwa dokter gigi yang memiliki tingkat pengetahuan rendah memiliki resiko 21 kali memiliki tindakan pembuangansampah yang buruk di tepat praktek dokter gigi.
\end{abstract}

Pelayanan kesehatan merupakan bagian penting dalam kesehatan. Pusat-pusat pelayanan kesehatan berupa rumah sakit, puskesmas, praktek dokter swasta (umum dan spesialis), bidan, dan klinik-klinik kesehatan lainnya, dalam setiap proses yang dilakukan akan menghasilkan bahan-bahan atau buangan hasil penyelenggaraan pelayanan kesehatan yang diberikan. Dalam hal ini, rumah sakit dan pusat-pusat pelayanan kesehatan sebagai penyelenggara 
pelayanan kesehatan justru menyumbangkan cukup banyak sampah atau limbah yang sangat berbahaya dan dapat mengancam kesehatan masyarakat serta keseimbangan lingkungan ${ }^{2}$.

Hingga saat ini, fokus dari isu lingkungan masih lebih berat kepada masalah limbah rumah tangga dan industri. Padahal limbah medis tidak kalah bahayanya, malah bisa jauh lebih berbahaya bagi lingkungan sekitar. Banyaknya sarung tangan, masker, kapas, dan jarum suntik bekas yang habis terpakai setiap harinya. Barang-barang tersebut sangat berpotensi untuk menularkan penyakit yang penularannya melalui cairan tubuh dan darah ${ }^{3}$.

Hal tersebut merupakan perlengkapan standar yang rutin digunakan, belum lagi bahan-bahan tambal yang mengandung bahan kimia dan merkuri, limbah pencucian film $X$-ray, pisau bedah dan benda tajam lain, serta bahan-bahan kimia beracun lain yang bila dibuang bersama-sama dengan sampah rumah tangga dapat meracuni air tanah atau terbawa dengan aliran pembuangan di selokan lalu ke sungai dan ke laut ${ }^{3}$.

Limbah medis salah satunya dihasilkan melalui praktek dokter gigi. Kebanyakan kita tidak menyadari bahwa tempat praktik dokter gigi dapat berpotensi sebagai asal limbah yang membahayakan lingkungan. Limbah berbahaya yang dimaksud adalah limbah merkuri dalam tambalan amalgam,alginat, akrilik, resin composite, air pembuangan, alat tajam, darah, jaringan, cairan X-rays dan lead foils, serta cairan pembersih atau cairan diesinfectants ${ }^{3}$.

Di kota Padang, terdapat 83 tempat praktek dokter gigi yang bersumber dari data Dinas Kesehatan Kota Padang tahun 2008-2012 . Setiap tempat praktek dokter gigi akan melayani pasiennya setiap hari. Banyaknya sampah medis yang akan dihasilkan setiap harinya melalui tempat praktek dokter gigi. Apabila sampah medis tersebut tidak dibuang pada tempat yang tepat maka akan menjadi sumber penyebaran penyakit bagi masyarakat sekitarnya. Berdasarkan uraian di atas maka peneliti ingin meneliti bagaimanakah pembuangan sampah medis di tempat praktek dokter gigi di kota Padang.

\section{METODE PENELTIAN}

Jenis penelitian ini adalah deskriptif yaitu penelitian yang hanya akan menggambarkan atau mendeskripsikan variabel tertentu dalam suatu penelitian tanpa mencari hubungan antar variabel ${ }^{4}$. Populasi pada penelitian ini adalah semua tempat praktek dokter gigi di kota Padang berjumlah 83 tempat yang bersumber dari data Dinas Kesehatan Kota Padang Tahun 2008-2012.

Sampel dalam penelitian ini diambil dengan metode simple random sampling yaitu pengambilan sampel secara acak sederhana dimana setiap anggota atau unit dari populasi mempunyai kesempatan yang sama untuk diseleksi sebagai sampel. Besar 
sampel ditentukan dengan menggunakan rumus estimasi proporsi sederhana ${ }^{5}$ :

$$
n=\frac{N}{1+N(d)^{2}}
$$

Teknik pengambilan sampel untuk masing-masing tempat adalah dengan simple random sampling yaitu teknik pengambilan sampel secara sederhana dimana dilakukan dengan menggunakan undian ${ }^{6}$.

Analisis univariat dimaksudkan untuk melihat gambaran distribusi frekuensi dari setiap variabel. Analisi bivariat dimaksudkan untuk mengetahui hubungan antara variabel independen terhadap variabel dependen. Untuk melihat hubungan ini dilakukan uji statistic dengan menggunakan uji Chi Square $\left(\mathrm{X}^{2}\right)$ dengan derajat kepercayaan $90 \%$.

Untuk melihat kemaknaan perhitungan statistik, digunakan batas kemaknaan 0,1 sehingga bila $\mathrm{P} \leq 0,1$ maka hasil statistik terdapat hubungan yang bermakna antara dua variabel atau Ha diterima, jika nilai $\mathrm{P}>0,1$ maka hasil perhitungan statistik tidak terdapat hubungan antara dua variabel atau Ha ditolak ${ }^{4}$.

\section{HASIL PENELITIAN}

Berdasarkan tabel 4.1 terlihat bahwa dokter gigi memiliki tingkat pengetahuan yang tinggi mengenai pembuangan sampah medis di tempat praktek dokter gigi $(75,6 \%)$ dibandingkan dengan dokter gigi yang memiliki tingkat pengetahuan yang rendah yaitu $(24.4 \%)$.

Tabel 4.1. Distribusi Tingkat Pengetahuan Dokter Gigi Mengenai Tindakan Pembuangan Sampah Di Tempat Praktek Dokter Gigi Tahun 2012

\begin{tabular}{c|c|c}
\hline Tingkat Pengetahuan & $\mathrm{f}$ & $\%$ \\
\hline Tinggi & 34 & 75,6 \\
Rendah & 11 & 24,4 \\
Total & 45 & 100 \\
\hline
\end{tabular}

Keterangan : $\mathrm{f}=$ frekuensi

Tindakan pembuangan sampah di tempat praktek dokter gigi dapat dilihat pada tabel 4.2 yaitu terlihat tindakan dokter gigi tergolong baik dalam pembuangan sampah $(66,7 \%)$ dibandingkan dengan yang buruk $(33,3 \%)$.

Tabel 4.2. Distribusi Tindakan Pembuangan Sampah di Tempat Praktek Dokter Gigi Tahun 2012

\begin{tabular}{c|c|c}
\hline $\begin{array}{c}\text { Tindakan Pembungan } \\
\text { Sampah }\end{array}$ & $\mathrm{f}$ & $\%$ \\
\hline Baik & 30 & 66,7 \\
Tidak Baik & 15 & 33,3 \\
Total & 45 & 100 \\
\hline \multicolumn{2}{c}{ Keterangan $: \mathrm{f}=$ frekuensi }
\end{tabular}

Untuk mengetahui hubungan tingkat pengetahuan dokter gigi terhadap tindakan pembuangan sampah di tempat praktek dokter gigi maka di uji menggunakan uji Chi-Square seperti yang terlihat pada tabel 4.3 
Tabel 4.3. Hubungan Tingkat Pengetahuan Dokter Gigi terhadap Tindakan Pembuangan Sampah di Tempat Praktek Dokter Gigi Tahun 2012

\begin{tabular}{|c|c|c|c|c|c|c|c|}
\hline \multirow{3}{*}{$\begin{array}{c}\text { Tingkat } \\
\text { Pengetahuan }\end{array}$} & \multicolumn{3}{|c|}{$\begin{array}{c}\text { Tindakan Pembuangan } \\
\text { Sampah }\end{array}$} & \multirow{2}{*}{\multicolumn{2}{|c|}{ Total }} & \multirow[t]{2}{*}{ p Value } & \multirow[t]{2}{*}{ OR $(95 \% \mathrm{CL})$} \\
\hline & Baik & \multicolumn{2}{|c|}{ Tidak Baik } & & & & \\
\hline & $\%$ & $f$ & $\%$ & $\mathrm{f}$ & $\%$ & 0,000 & 21,0 \\
\hline Tinggi & 82,4 & 6 & 17,6 & 34 & 100 & & \\
\hline Rendah & 18,2 & 9 & 81,8 & 11 & 100 & & \\
\hline Total & 66,7 & 15 & 33,3 & 45 & 100 & & \\
\hline
\end{tabular}

Berdasarkan tabel 4.3 hasil uji statistik menunjukkan $\mathrm{p}<\alpha(0,05)$, sehingga dapat ditarik kesimpulan terdapat hubungan yang bermakna antara Tingkat Pengetahuan Dokter Gigi terhadap Tindakan Pembuangan Sampah di Tempat Praktek Dokter Gigi Tahun 2012. Odds Ratio (95\% CL $=3,6$ $123,0)$ dapat disimpulkan bahwa dokter gigi yang memiliki tingkat pengetahuan rendah memiliki resiko 21 kali memiliki tindakan pembuangan sampah yang buruk di tepat praktek dokter gigi.

\section{PEMBAHASAN}

Penelitian ini menunjukkan bahwa dokter gigi memiliki tingkat pengetahuan yang tinggi yaitu $75,6 \%$ dan memiliki tingkat pengetahuan rendah sebanyak $24,4 \%$ mengenai tindakan pembuangan sampah di tempat praktek dokter gigi. Berdasarkan kuisioner yang diberikan dokter gigi mengaku bahwa 97,8\% ada pemisahan sampah medis dengan sampah non medis, 2,2\% pemisahan tidak disesuaikan dengan kode warna kantong sampah, 2,2\% tempat sampah tidak pernah didesinfeksi setelah penampungan dikosongkan, $73,3 \%$ memiliki jangka waktu pengangkutan sampah dari setiap ruangan, $80 \%$ sampah farmasi/obatobatan yang rusak dan kadaluarsa dikembalikan kepada distributor, $80 \%$ cara pemusnahan yang dilakukan adalah dengan dibakar dengan incerator.

Tempat praktek dokter gigi yang aman terhadap lingkungan merupakan suatu hal yang harus dipersiapkan oleh dokter gigi. Untuk mendukung hal ini pengetahuan dokter gigi yang akan praktek dibantu dengan peraturan dinas kesehatan yang mendapat rekomendasi dari PDGI perlu diketahui sebelumnya. Pengetahuan tentang praktik yang aman terhadap lingkungan sudah harus disiapkan selama proses pendidikan, antara lain pemikiran terhadap perlindungan kesehatan pasien,dokter gigi sendiri, personil kesehatan, limbah praktik dan lingkungan praktik ${ }^{7}$.

Penelitian ini juga menunjukkan bahwa dokter gigi memiliki tindakan yang baik $(66,7 \%)$ dan buruk $(33,3 \%)$ dalam pembungan sampah di tempat praktek dokter gigi. Berdasarkan observasi yang dilakukan $84,4 \%$ memiliki tempat penampungan sampah pada kamar mandi, 64,4\% tempat 
penampungan didesinfeksi setelah dikosongkan, $75,6 \%$ tempat penampungan sampah tahan terhadap benda tajam dan runcing, 95,6\% tampungan sampah medis dan non medis dipisahkan, dan tidak ditemukan dokter gigi yang memberi warna padatampungan sampah baikitu warna merah, kuning, ungu, maupun coklat.

Menurut (Depkes RI, 2002) tempattempat penampungan sampah hendaknya memenuhi persyaratan minimal sebagai berikut bahan tidak mudah karat, kedap air, terutama untuk menampung sampah basah, bertutup rapat, mudah dibersihkan, mudah dikosongkan atau diangkut, tidak menimbulkan bising, tahan terhadap benda tajam dan runcing. Kantong plastik diangkat setiap hari atau kurang sehari apabila 2/3 bagian telah terisi sampah. Untuk bendabenda tajam hendaknya ditampung pada tempat khusus (safety box) seperti botol atau karton yang aman (Depkes RI, 2004).

Secara khusus uji statistik ChiSquare menunjukkan $\mathrm{p}<\alpha(0,05)$, sehingga dapat ditarik kesimpulan terdapat hubungan yang bermakna antara Tingkat Pengetahuan Dokter Gigi terhadap Tindakan Pembuangan Sampah di Tempat Praktek Dokter Gigi Tahun 2012. Odds Ratio (95\% CL $=3,6$ 123,0) dapat disimpulkan bahwa dokter gigi yang memiliki tingkat pengetahuan rendah memiliki resiko 21 kali memiliki tindakan pembuangan sampah yang buruk di tepat praktek dokter gigi.

\section{KESIMPULAN}

Berdasarkan hasil penelitian maka dapat diambil kesimpulan sebagai berikut:

1. Sebagian besar dokter gigi memiliki tingkat pengetahuan yang tinggi mengenai tindakan pembuangan sampah medis di tempat praktek dokter gigi.

2. Sebagian besar dokter gigi memiliki tindakan pembuangan sampah yang baik di tempat praktek dokter gigi.

3. Ada hubungan antara tingkat pengetahuan dokter gigi dengan tindakan pembuangan sampah di tempat praktek dokter gigi tahun 2012 dengan hasil uji Chi-Square $\mathrm{p}$ $(0,00)<\alpha(0,05)$.

4. Odds Ratio $(95 \% \mathrm{CL}=3,6-123,0)$ dapat disimpulkan bahwa dokter gigi yang memiliki tingkat pengetahuan rendah memiliki resiko 21 kali memiliki tindakan pembuangan sampah yang buruk di tepat praktek dokter gigi.

\section{SARAN}

1. Bagi Peneliti

Perlu dilakukan penelitian lebih lanjut mengenai fakor-faktor yang berhubungan dengan tindakan pembungan sampah di tempat praktek dokter gigi.

\section{Bagi Dokter gigi}

Disarankan kepada semua dokter gigi yang memiliki tempat praktek agar dapat melakukan pembuangan sampah maupun limbah yang berasal dari tempat prakteknya sesuai dengan ketentuanyang berlaku. Sehingga tidak menimbulkan 
penyakit terhadap masyarakat di

lingkungan praktek dokter gigi tersebut.

\section{DAFTAR PUSTAKA}

1. Pruss, A. 2005. Ilmu Kesehatan Masyarkat. http://med.unhas.ac.id/fkuhanatomi/index php?option $=$ com content $\&$ view $=\operatorname{article} @, \mathrm{id}=$ 52:ilmu-kesehatanmasyarakat\&catid=1:latest-news.pdf. ( $20 \mathrm{mei}$ 2012)

2. Mae.

2011

http://www.pdf.com/doc/24852587/Kelompok nya-Mae ( 29 Mei 2012)
3. Mozartha, Martha. 2008. Dentists, Let's Go Green. Artikel Klik Dokter Menuju Indonesia Sehat. http://klikdokter.com. ( 25 Juli 2012)

4. Budiarto.Biostatistik Untuk Kedokteran dan Kesehatan Masyarakat. EGC. Jakarta. 2002. Hlm: 84-85

5. Notoatmojo,S. Metodologi Penelitian Kesehatan. Rineka Cipta. Jakarta. 2005.Hlm: 85-92

6. Sabri, L dan Hastono. 2010. Statistik Kesehatan. Bandung: Raja Grafindo.

7. Fareham. 2009. Policy for the handling and disposal healthcare waste.http://.farehamwww.nhs.uk/op-w2health-care-waste pdf.(21Mei2012) 